\section{Um olhar para as familias, de dentro e de perto}

Luiz Fernando DIAS DUARTE e Edlaine de CAMPOS GOMES. Três famílias: identidades e trajetórias transgeracionais nas classes populares. Rio de Janeiro, FGV, 2008. 313 páginas.

\section{Heloisa Buarque de Almeida}

O que levaria um antropólogo conhecedor das vicissitudes e dos problemas de se falar da intimidade da vida alheia a pesquisar sua própria família? O que levaria então dois deles a fazer essa empreitada conjuntamente? Essa é certamente a primeira questão que vem à mente ao nos depararmos com o livro premiado pela Anpocs em 2009: Três famílias: identidades e trajetórias transgeracionais nas classes populares. Luiz Fernando Dias Duarte, professor do Museu Nacional, com um trabalho bastante reconhecido com famílias de classe trabalhadora, e Edlaine de Campos Gomes, então pesquisadora do Cebrap e agora professora da UFRJ, com estudos sobre religião, unem-se numa proposta muito particular e mesmo incomum. Não é surpresa que se inspirem na proposta de "história de família" como método proposto por um artigo ${ }^{1}$ citado logo no início do livro. O surpreendente aqui é a seleção das famílias. Os autores tomam três famílias - os Costa, família que Duarte acompanha há trinta anos em suas pesquisas, os Duarte, família paterna do autor, e os Campos, família materna da autora -, e a partir das histórias dessas famílias fazem reflexões antropológicas sobre relaçōes familiares, arranjos domésticos, religião e conversões, identidades e transformaçôes de uma geração para a outra. $\mathrm{O}$ único tema não explicitado no título do livro que merece destaque é a religião.

O capítulo inicial logo responde à questão. Edlaine sempre foi pesquisadora de seu próprio contexto social - aluna da universidade federal, oriunda de camadas populares e da Baixada Fluminense, tornou-se informante e mesmo assistente de pesquisa sobre as periferias urbanas e a expansão do pentecostalismo. Seu aprendizado de reflexão social era, assim, dedicado a um mundo que ela conhecia de perto e do qual, contudo, ao caminhar na sua formação profissional, se distanciava cada vez mais.
Com uma trajetória incomum naquele contexto social, resultante de um casal que incentivou os filhos a estudar, termina por se reaproximar da família extensa em movimento gerado pela pesquisa e pela percepção de que tinha, ali mesmo, "em casa", casos exemplares de trajetórias de conversão ao pentecostalismo. Com esse foco em mente, a autora passou a participar muito mais assiduamente de festas e momentos de congraçamento com os parentes, e a própria motivação da pesquisa gerou novas formas de se relacionar com eles. No grupo de pesquisa, a reflexão de Edlaine Gomes levou Luiz Fernando Duarte a rever a trajetória de sua família paterna, descobrindo então que se tratava de uma família oriunda, muito mais do que ele pensava, das classes populares. Em sua análise, há certo deslocamento temporal, e mais referência ao passado do que a situações contemporâneas. Certamente foi uma escolha de Duarte para preservar a intimidade atual da família. $\mathrm{O}$ autor procura também tratar dos mesmos temas que Edlaine desenvolve. A terceira família, dos Costa, apesar de não ser parente de nenhum dos autores, é uma família que Duarte tem bastante intimidade por ser parte de suas pesquisas de campo há três décadas - quem já leu seus trabalhos anteriores, como seu livro Da vida nervosa nas classes trabalhadoras urbanas, conhece bem seus casos de "nervoso". A partir dessa família, o autor reflete sobre as relações de parentesco, o cotidiano familiar, a casa, a religião, as trajetórias individuais e as transformações de uma geração à outra.

Neste livro, não se usa o recurso aos pseudônimos, pois nomes e sobrenomes de cada grupo familiar são citados. Certamente, a intenção não foi expor a intimidade familiar, mas deve ter sido delicado e talvez tenha gerado mágoas a maneira tão direta em que o livro foi escrito, ainda que tenha sido tudo autorizado. Quantas vezes as pessoas com quem convivemos numa pesquisa de campo, ao verem o resultado final do trabalho, se ofendem, não compreendem e se sentem "traídas" pelo que foi dito (ou pelo o que não foi dito) e pela interpretação que fazemos de suas vidas. Ademais, "a vida" vai muito além dos inevitáveis recortes que somos obrigados a fazer durante o processo de análise. O leitor fica, pois, imaginando os familiares católicos de Edlaine Gomes diante dos recém-convertidos ao pentecostalismo, 
depois de tanto os criticarem. Há passagens em que percebemos os autores realmente se esforçando para não contar "tudo", outras em que revelam a decisão de não ir muito a fundo nas perguntas, uma vez que o que se esconde parece ser um segredo. Mas certamente, há segredos que vêm à tona!

É na comparação entre essas famílias que se iluminam vários aspectos da vida social. Cada um dos primeiros três capítulos é focado em uma família; nos três capítulos seguintes, delineiam-se comparações e análises. Em "Casa e família nas classes populares" discute-se a presença e a importância que a "casa" pode assumir, retomando um termo clássico dos estudos de parentesco, mas com outro sentido. Nas famílias populares, a residência coletiva cresce de acordo com a reprodução familiar, seja no formato de quintais, puxadinhos, lajes, ou mesmo uma varanda que acolhe todos às refeições. "Quintal" tem se tornado uma categoria importante de compreensão dos arranjos domésticos. A presença de uma casa de referência que permita essas adaptaçôes cria uma rede de ajuda fundamental para os indivíduos, e o livro insere-se certamente no importante diálogo com a bibliografia brasileira sobre as camadas populares, mas aponta também como o tema tem surgido na etnografia de outros países (como as pesquisa em Portugal). Além da casa, a figura do casal que é lembrado como tendo de algum modo fundado o ramo da família e provavelmente construído a casa que é também uma referência. Dado esse arranjo doméstico de intensa proximidade, sobressai a importância da figura dos sogros. Uma das famílias tem um arranjo mais matrifocal são as filhas e seus maridos que coabitam com os pais - e outra, um arranjo mais patrifocal - são os filhos que trazem suas esposas para morar junto, e as filhas saem para morar com os sogros. Aqui é a figura da sogra que determina muito das escolhas religiosas. Certamente esses estudos levam a uma discussão mais aprofundada sobre uma espécie de "sograria" que está em jogo. ${ }^{2}$ A cozinha como espaço de sociabilidade central, recorrente em pesquisas em outros países, é também destacada no livro. A casa é o centro acolhedor de muita gente, muitas vezes de maneira passageira.

No capítulo seguinte, as "Condições diferenciais de reprodução" são foco de reflexão. Compa- rando a situação particular dos Duarte em relação às outras famílias, constatam-se as chances e as possibilidades que um local de moradia mais próximo ao centro pode proporcionar, assim como o acesso a empregos públicos. Em contrapartida, a moradia em bairro periférico pode gerar mais precariedade e dificuldade de acesso a escolas, serviços e espaços de lazer. O trabalho é fundamental neste ponto: nas famílias Costa e Campos a maioria dos adultos sobrevive do pequeno comércio, de ocupações sem nenhuma garantia trabalhista, ou como autônomos. As diferenças nas relações entre sujeitos, instituiçôes e espaços são explicadas por fatores distintos, como o local de moradia, o acesso à educação, ou a situação do trabalho em termos de direitos ou precarização.

Algumas possibilidades - como o acesso a e a busca por educação formal - de fato permitem a ascensão social ou a possibilidade de auto-afirmação e individualização, nos termos discutidos no último capítulo. Nesse sentido, Duarte retoma uma discussão cara a todo seu percurso como pesquisador, centrando-se nos processos de auto-afirmação e distanciamento da casa e das lógicas de pertencimento familiar que muitas vezes ordenam de maneira marcante a vida cotidiana em arranjos domésticos como os analisados.

O livro é apaixonante para pesquisadores que trabalham com família, seja no Brasil, seja no exterior, e obrigatório para estudiosos do campo da religião e para aqueles que analisam as transformaçôes sociais e culturais. Evidenciam-se no decorrer da leitura, de uma geração à outra, mudanças nas condições de acesso à educação, de um lado, e certa precarização crescente do trabalho manual ou não especializado, de outro. De uma geração à outra a moralidade em relação ao casamento se transforma dos casamentos necessariamente religiosos para um maior respeito por uniōes informais, que se revela em expressões como, por exemplo, "juntado com fé, casado é". Os habitantes mudam, as geraçōes passam, mas é a "casa" que se mantém como referência.

Essa descrição tão de perto e tão de dentro permite uma etnografia muito afetiva e reveladora dos conflitos que estão em jogo. A leitura de Três famílias provoca reflexões mais amplas sobre as pesquisas acerca de famílias, e leva-nos a pensar de manei- 